JBL 131, no. 3 (2012): 443-454

\title{
Not Just Any King: Abimelech, the Northern Monarchy, and the Final Form of Judges
}

\author{
BRIAN P. IRWIN \\ brian.irwin@utoronto.ca \\ Knox College, Toronto, ON M5S 2E6, Canada
}

\section{Theme And Structure in the Book of Judges}

Over the past two and a half decades a number of significant studies have altered the way in which the book of Judges is studied and understood. In 1987, Samuel Dragga drew attention to elements in the book that highlight the failure of Saul. ${ }^{1}$ A short while later in this journal, Mark Zvi Brettler advanced the view that a major theme in Judges is the promotion of Judah, often at the expense of Benjamin and the northern tribes. From this, Brettler suggested that much in the book should be read as allegory in which the Davidic dynasty is elevated at the expense of the house of Saul and the northern monarchy. ${ }^{2}$ Recently, others have built on the work of these scholars to argue persuasively and at greater length for the presence of anti-Saulide polemic throughout the book. ${ }^{3}$

An earlier version of this paper was delivered at the annual meeting of the Canadian Society of Biblical Studies, June 1-3, 2008, at the University of British Columbia, Vancouver, BC. My thanks go to Ehud Ben Zvi for his comments and helpful suggestions made at that time. Thanks are also owed to the JBL reviewers, whose helpful comments led to many further revisions.

${ }^{1}$ Dragga, "In the Shadow of the Judges: The Failure of Saul," JSOT 38 (1987): 39-46.

2 Brettler, "The Book of Judges: Literature as Politics," JBL 108 (1989): 395-418. See recently the critique of this position by Gregory Wong ("Is There a Direct Pro-Judah Polemic in Judges?" SJOT 19 [2005]: 84-110) and the response by Serge Frolov ("Fire, Smoke, and Judah in Judges: A Response to Gregory Wong," SJOT 21 [2007]: 127-38).

${ }^{3}$ Robert H. O'Connell, The Rhetoric of the Book of Judges (VTSup 63; Leiden: Brill, 1996); Yairah Amit, "The Saul Polemic in the Persian Period," in Judah and the Judeans in the Persian Period (ed. Oded Lipschits and Manfred Oeming; Winona Lake, IN: Eisenbrauns, 2006), 647-61. 
Alongside the thematic studies already mentioned have been others that have focused on structure. ${ }^{4}$ The result of this is that today the consensus among scholars sees Judges as having a tripartite structure consisting of Prologue/Introduction (1:1-3:6), ${ }^{5}$ Body (3:7-16:31), and Epilogue/Appendix/Conclusion (chs. 17-21). ${ }^{6}$ The central section of Judges consists of narratives and notices covering the careers of twelve charismatic leaders of Israel. In both structure and content the final form of the book depicts the system of judges as providing failed leadership. In the final form of the book, the judges are divided into two groups-five preceding Abimelech and seven following him. Within this schema, the first group (3:7-8:28) is portrayed as having been effective. Of these judges, all but Shamgar receive the commendation that, as a result of their work, "the land was at peace" $(3: 11,30 ; 5: 31$; $8: 28)$. Of Shamgar, it is positively noted that "he saved Israel" (3:31). Following Abimelech, seven judges are listed (10:1-16:31). This larger block of judges differs from the first in that nowhere in this section does the statement that the "land was at peace" appear. Individually and as a whole, the judges in the second group rule for shorter periods than those of the first group. ${ }^{7}$ The greater number of judges in this second group (seven versus five in the first group), along with their lack of success and shorter tenures, contributes to the sense that the system of judges is breaking down.

While even the "successful" judges are portrayed as falling short, ${ }^{8}$ the failure

${ }^{4}$ J. P. U. Lilley, “A Literary Appreciation of the Book of Judges,” TynBul 18 (1967): 94-102; David W. Gooding, "The Composition of the Book of Judges," in Eretz-Israel, Archaeological, Historical and Geographical Studies: H. M. Orlinsky Volume (ErIsr 16; Jerusalem: Israel Exploration Society, 1982), 70-79.

${ }^{5}$ Where variation exists, it is around the point at which the introduction ends. Arthur Ernest Cundall is typical of an older view in ending the introduction at 2:5 ("Judges-An Apology for the Monarchy," ExpTim 81 [1969-70]: 178-81; cf. George Foot Moore, A Critical and Exegetical Commentary on Judges [ICC; Edinburgh: T\&T Clark, 1895], xiii-xv). Brettler ("Book of Judges: Literature as Politics," 396) ends the introduction at 2:10, understanding it to provide the background of the conquest of Canaan. On the basis of syntax and content, Trent C. Butler ends the introduction at 2:23 (Judges [WBC 8; Nashville: Thomas Nelson, 2009], 9-12).

${ }^{6}$ Marvin A. Sweeney acknowledges that the three-part structure is the consensus view, but he argues instead for a two-part structural schema consisting of chs. 1-2 and 3-21 ("Davidic Polemics in the Book of Judges," VT 47 [1997]: 517-29).

${ }^{7}$ The years given for the judges of the first group refer to the years of peace that resulted from their work and so provides a measure of their effectiveness. Within this group, Othniel brings forty years of peace, Ehud eighty years, Deborah forty years, and Gideon forty years. No chronological data are given for Shamgar (3:31). With the judges of the second group, the chronological data describe the length of time they led Israel with no reference to years of peace: Tola (twenty-three years), Jair (twenty-two years), Jephthah (six years), Ibzan (seven years), Elon (ten years), Abdon (eight years), and Samson (twenty years). On the whole, the dates allotted to the first group amount to two hundred years, while those of the second group total only ninety-seven years.

${ }^{8}$ The theme of the failure of the judges is anticipated even in the section on Gideon, the last of the first group of effective judges. During his time, "rebellion" by the tribe of Ephraim was only

This article was published in JBL 131/3 (2012) 443-54, copyright (C) 2012 by the Society of Biblical Literature. To purchase copies of this issue or to subscribe to JBL, please contact SBL Customer Service by phone at 866-727-9955 [toll-free in North America] or 404-727-9498, by fax at 404-727-2419, or visit the online SBL Store at www.sbl-site.org. 
of the system of judges is most spectacularly demonstrated in the careers of the final two major judges-Jephthah and Samson. In 12:1-6, the rash behavior of Jephthah results in the sacrifice of his daughter. Further, in the time of Jephthah (12:1-6), tribal solidarity breaks down and civil war erupts with Ephraim. In 14:1, the nazirite Samson treats his vows with disdain by seeking to marry a Philistine woman. Later, he defiles himself (and also his parents) by eating honey from the carcass of an unclean beast (14:8-9), and in 16:1 he visits a prostitute. Far from liberating the people of Israel, Samson's activity leads to his rejection and the collective admission by the people of Judah that "the Philistines are rulers over us" (Judg 15:11).

In light of the above, the following outline may be proposed based on the content and key formulae ${ }^{9}$ found in the book. Within this outline, the Abimelech narrative occupies a central place in the structure of the final form of the book.

I. Introduction $(1: 1-3: 6)$

II. The Judges of Peace (3:7-8:28)

III. The Abimelech Incident (8:29-9:57)

IV. The Judges of Decline (10:1-16:31)

V. Conclusion: The Collapse of the System and the Need for a King $(17: 1-21: 25)$

From the foregoing assessment of structure, and particularly from the work of Brettler and others cited above, ${ }^{10}$ it is clear that the book of Judges exists to address the issue of leadership in Israel. The juxtaposition of an initial, successful group of judges with a second, and larger, unsuccessful group shows that the system of judges failed to meet the need for which it was created. This point is forcefully underscored in the conclusion of the book (17:1-21:25) with its twin examples of moral and covenant failure and emphasis on the need for alternative leadership. ${ }^{11}$ Each story in the conclusion demonstrates that unless the current system is changed the

narrowly averted (8:1-3), while at the end of his life an ephod of his own construction becomes a snare for himself, his family, and all Israel (8:22-27). On how a progressively disrupted narrative framework reflects the collapse of the judges, see Susanne Gillmayr-Bucher, "Framework and Discourse in the Book of Judges," JBL 128 (2009): 687-703.

${ }^{9}$ The account of each judge (save Shamgar, Ibzan, Elon, and Tolah) is introduced with some variation on the basic formula "the Israelites did evil in the eyes of Yahweh" (3:7, 12; 4:1; 6:1; 13:1). Likewise, the account of each judge concludes with a formula that the land had peace (Othniel, 3:11; Ehud, 3:30; Deborah, 5:31; Gideon, 8:28), an indication of success (Shamgar, 3:31), or an austere career summary and death notice (Tola, 10:2; Jair, 10:5; Jephthah, 12:7; Ibzan, 12:10; Elon, 12:12; Abdon, 12:15). The end of Samson's formal career is indicated in 15:20 by the simple statement that "he led Israel for twenty years in the days of the Philistines."

${ }^{10}$ See n. 2 above.

${ }^{11}$ Judges 17:1-18:31 recounts the abdication and idolatry of the Danites, while 19:1-21:25 emphasizes the wickedness and canaanization of the people of Gibeah.

This article was published in JBL 131/3 (2012) 443-54, copyright (C) 2012 by the Society of Biblical Literature. To purchase copies of this issue or to subscribe to JBL, please contact SBL Customer Service by phone at 866-727-9955 [toll-free in North America] or 404-727-9498, by fax at 404-727-2419, or visit the online SBL Store at www.sbl-site.org. 
Israelites will end up just like the Canaanites and others they were supposed to displace.

In the central section of Judges (3:7-16:31), the figure of Abimelech stands out as unique. ${ }^{12}$ Unlike the other figures in the book, Abimelech is depicted as a king and not a judge. In contrast to his father, Gideon, Abimelech is not called by God but rises to power by an appeal to popular will (9:1-3), by hiring mercenaries (9:4), and by eliminating potential rivals through murder (9:5). From the narrative describing his rule, it is clear that he does not deliver Israel from anything-no external enemy is present or repulsed. Quite to the contrary, under Abimelech, the hill country of Ephraim is characterized internally by instability and violence. Finally, his account ends without the expected reference to deliverance, years served, or burial, but rather with the notice that his fate was divine repayment for his wickedness (9:57). If Abimelech has so little in common with the judges of Israel, it is worth asking why his narrative is placed so centrally in Judges and what function it serves in the final form of the book.

Wolfgang Bluedorn has argued that the Abimelech narrative stands as a polemic against Baalism, demonstrating that Baal is not divine. Problematic for this view, however, is the fact that the speech of Jotham-which Bluedorn sees as setting the theme for the Abimelech narrative-makes no direct mention of Baal. ${ }^{13}$ To the contrary, a careful reading of the speech shows it to be concerned with the issue of legitimate versus illegitimate human leadership. ${ }^{14}$ In addition, it should be noted that nowhere in the Abimelech narrative do the citizens of Shechem make appeal to Baal for deliverance; when attacked by Abimelech, the temple to which they flee is identified as that of El-berith (9:46).

In his study of the rhetoric of Judges as a whole, Robert H. O'Connell has cautiously offered that the Abimelech narrative may include parallels with the life of Saul in a way intended to intensify the criticism of Israel's first king. ${ }^{15}$ Drawing on the work of Moshe Garsiel, ${ }^{16}$ O'Connell briefly presents eight parallels that, on the whole, are too general to be convincing. Among these are the details that both Abimelech and Saul have rivals in Abimelech's half-brothers and David, respectively, and that Abimelech slaughters the seventy sons of Jerubbaal and the people of Shechem while Saul slaughters the eighty-five priests of Nob and the people of Nob. Of the parallels that O'Connell mentions, the most compelling is the request

\footnotetext{
${ }^{12}$ See Baruch Halpern, “The Rise of Abimelek Ben-Jerubbaal," HAR 2 (1978): 80-81.

${ }^{13}$ Bluedorn, Yahweh Versus Baalism: A Theological Reading of the Gideon-Abimelech Narrative (JSOT Sup 329; Sheffield: Sheffield Academic Press, 2001), 183, 210-12.

${ }^{14}$ See Butler, Judges, 234; Tammi J. Schneider, Judges (Berit Olam; Collegeville, MN: Liturgical Press, 2000), 139.

${ }^{15}$ O'Connell, Rhetoric of the Book of Judges, 291-93.

${ }^{16}$ Garsiel, The First Book of Samuel: A Literary Study of Comparative Structures, Analogies and Parallels (Ramat Gan: Revivim, 1985), 98-99.
} 
for death at the hand of an armor-bearer, but even here significant differences exist. $^{17}$

If the Abimelech narrative does not function well as either anti-Baal or antiSaulide polemic, then another explanation must be sought for the role played by this material in the final form of Judges.

\section{The Abimelech Narrative as Anti-northern Polemic}

The rejection of the system of charismatic rule in favor of monarchy as forcefully expressed in Judges would naturally have invited several questions. Faced with the pro-Judean stance of the book, some ancient readers might have legitimately objected, "Our first king was from the tribe of Benjamin; why not a kingship from the line of Saul?" The denigration of Benjamin throughout the book, but especially in its conclusion, addresses this objection. From the time of Rehoboam on, however, the elephant in the room was the northern monarchy under Jeroboam I and his successors, and no discussion of leadership in Israel would have been complete without addressing the issue of its legitimacy. Given the extended war that dominated much of the first century following the dissolution of the united monarchy, ${ }^{18}$ the question of which kingdom would dominate-Judah or Israel-was an open one. This question of legitimacy extended even into the postexilic era, when the conflict pitted the returned Judean exiles against the occupants of Samaria. In what follows, it will be argued that, in the final form of the book of Judges, the Abimelech narrative (8:29-9:57) has been placed and shaped in order to address this one outstanding issue. It is to this central section of Judges and to this issue that we now turn.

Many scholars have regarded the Abimelech material as some form of antimonarchic tract. ${ }^{19}$ The difficulty with this view is that it recognizes the presence of

\footnotetext{
${ }^{17}$ For Abimelech, death comes at the end of a successful campaign to put down a rebellion at Thebez. There, Abimelech dies at the hand of his armor-bearer, who acts at his master's behest so that it will not be said that "a woman killed him" (פן־יאמרו לי אשה הרגתהו) (9:54). In 1 Samuel 31, the Israelites are fighting a losing defensive battle against the Philistines. Facing death, Saul asks his armor-bearer to kill him so that he would not suffer abuse or torture at the hands of the enemy (1 Sam 31:4). In this case, however, the armor-bearer refuses and Saul is left to take his own life by falling on his sword. If the author of Judges wished to draw a parallel between the deaths of Abimelech and Saul, then it is odd that the two episodes do not correspond more closely in vocabulary or action.

${ }^{18} 1$ Kings 14:29; 15:6-8, 16-22; 2 Chr 11:1-12; 13:13-20; 15:5, 8-9; 16:1-6.

19 Wolfgang Richter, Traditionsgeschichtliche Untersuchungen zum Richterbuch (BBB 18; Bonn: P. Hanstein, 1963), 285-86; Martin Buber, Kingship of God (3rd ed.; New York: Harper \& Row, 1973), 75; Frank Crüsemann, Der Widerstand gegen das Königtum: Die antiköniglichen Texte des alten Testamentes und der Kampf um den frühen israelitischen Staat (WMANT 49; Neukirchen-
}

This article was published in JBL 131/3 (2012) 443-54, copyright $\odot 2012$ by the Society of Biblical Literature. To purchase copies of this issue or to subscribe to JBL, please contact SBL Customer Service by phone at 866-727-9955 [toll-free in North America] or 404-727-9498, by fax at 404-727-2419, or visit the online SBL Store at www.sbl-site.org. 
two contradictory emphases within the same book-elements at the end of the book that clearly endorse the idea of monarchy (e.g., 17:6;18:1;19:1;21:25) ${ }^{20}$ and a section central to the book that-according to this idea-argues decisively against it. In assessing this view, one is left wondering how these contrary emphases could have come to coexist. A helpful modification of this view has been to recognize that the objection to monarchy in the Gideon and Abimelech narratives is not to kingship per se but to how leaders are chosen. ${ }^{21}$ In light of the often turbulent relations between Judah and Israel, however, another way of resolving this difficulty is to understand the Abimelech narrative not as a blanket condemnation of monarchy, but of one specific form of monarchy - that of the northern kingdom, which was in competition with the dynasty of David and where kings were raised by popular acclaim.

Scholarly consensus sees the Abimelech narrative as comprising Judg 9:1-57. A close look at the formulae present in the text, however, suggests a slightly different division. As has been noted above, the central section of Judges is structured around the activities of twelve charismatic leaders with the conclusion of each account typically marked by a formulaic summary of the judge's work. ${ }^{22}$ In the case of Gideon, this summary comes in 8:28 with the statement that "the land enjoyed peace for forty years." While the verses that follow continue to talk about Gideon, they do so only to introduce, and establish the connection with, Abimelech. This suggests that, contrary to the view of most commentators, the Abimelech material actually encompasses 8:29-9:57, ${ }^{23}$ with 8:29-35 likely being a transitional paragraph included to provide a bridge between originally separate Gideon and Abimelech stories. ${ }^{24}$ The unity of this block of material in the final form of the text is

Vluyn: Neukirchener Verlag, 1978), 32-42; J. Alberto Soggin, Judges (OTL; Philadelphia: Westminster, 1981), 176-77; Susan Niditch, Judges: A Commentary (OTL; Louisville: Westminster John Knox, 2008), 114, 116.

${ }^{20}$ This difficulty is recognized by Wong, who seeks to resolve it by arguing that the term מלך in the expression "there was no מלך in Israel" refers not to a human king but to Yahweh (Compositional Strategy of the Book of Judges: An Inductive, Rhetorical Study [VTSup 111; Leiden: Brill, 2006], 212-23). As will be demonstrated below, however, such a solution is unnecessary if the Abimelech narrative is understood to address not kingship in general but one particular form of kingship. See Yairah Amit, The Book of Judges: The Art of Editing (Biblical Interpretation Series 38; Leiden/Boston: Brill, 1999), 92-96.

${ }^{21}$ O'Connell, Rhetorical Strategy of Judges, 291; Butler, Judges, 234.

${ }^{22}$ E.g., Othniel, Judg 3:11; Ehud 3:30; Deborah, 5:31. Among the first group of judges, Shamgar is unique in the paucity of material referring to him (a single verse) and the fact that this material does not conclude with the expected announcement that the land "enjoyed peace." Of Shamgar it is said only, "He too saved Israel" (3:31).

${ }^{23}$ An exception is Bluedorn (Yahweh Versus Baalism, 17-18, 51-56). While he recognizes 8:29-9:57 as the boundaries of the Abimelech narrative, he goes on to treat it and the preceding Gideon narrative as a single literary-theological unit.

${ }^{24}$ The transitional character of 8:29-35 is clear from the interchange here between the 
indicated also by (1) the repetition of the key vocabulary ירבעל ("Jerubbaal"), שבעים ("seventy"), שכם ("Shechem"), and אבימלך ("Abimelech") in 8:29-31 and 9:56-57, which frame the narrative, and (2) by the use of a parallel phrase including a distant antonymic word pair in 8:35 הטובה אשר עשה, "good that he [Gideon] had done”) and 9:56 (רעת אבימלך אשר עשה, "evil that Abimelech had done"). ${ }^{25}$ Thus, at the beginning and end of the section, Abimelech's connection with Shechem and the seventy other sons of Jerubbaal is established, and the good that Gideon had done is contrasted with the wickedness that Abimelech had done. A further indication that 8:29-9:57 is a distinct block of material is the fact that within it, the unmodified name "Jerubbaal" dominates as a name of Gideon.

For the proposal under discussion, the main point of interest is the possible connection between this Abimelech material and the early northern monarchy. Most telling in this regard is the fact that Abimelech establishes his despotic monarchy at Shechem, the city that became the first capital of the northern kingdom of Israel. In the case of Abimelech, an Ephraimite from the family of Gideon rejects his family and establishes a monarchy in Shechem (Judg 9:6). In the case of the late united monarchy, another Ephraimite, Jeroboam I, rejects the court of Solomon and also establishes a monarchy with its capital in Shechem (1 Kgs 12:1, 20). ${ }^{26}$

Other elements demonstrate a connection between the Abimelech narrative and the early northern monarchy. A clear verbal and contextual connection between the Abimelech narrative and the time of Jeroboam I comes with the note in Judg 9:4 that Abimelech hires אנשים ריקים ("worthless men”) to support him in his efforts to seize power. Strikingly, in $2 \mathrm{Chr}$ 13:7, Jeroboam I assembles an identical group (אנשים ריקים) for precisely the same purpose. The connection between these two references is strengthened by the fact that this phrase occurs only three times in all of the MT, occurring elsewhere only in the story of Jephthah (Judg 11:3). Judges 9 and 2 Chronicles 13 are also connected by marked similarities

names Gideon and Jerubbaal, providing a link between chs. 6-8, where "Gideon" dominates (Jerubbaal appearing only twice-Judg 6:32; 7:1), and ch. 9, where Jerubbaal is used exclusively. See Amit, Book of Judges, 100-101; Moore, Judges, 236; C. F. Burney, The Book of Judges with Introduction and Notes (2nd ed.; London: Rivingtons, 1920), 266.

${ }^{25}$ On the use of distant word pairs in poetry and prose, see Wilfred G. E. Watson, Classical Hebrew Poetry: A Guide to Its Techniques (JSOTSup 26; Sheffield: JSOT Press, 1984), 134-35; and Mitchell Dahood, "Ugaritic-Hebrew Parallel Pairs," RSP 1:80-81.

${ }^{26}$ A possible allusion to Jeroboam I may come in Judg 9:6, where Abimelech is made king by all of the leading citizens of Shechem as well as "all of Beth Millo"/"the entire house of Millo" (וכל־בית מלוא). It is interesting to note that in the account of Jeroboam's rebellion against Solomon, it is mentioned that Jeroboam first rose to prominence as a result of the work he did in overseeing construction of the Millo in Jerusalem (1 Kgs 11:27-28). If a connection with $1 \mathrm{Kgs}$ 11:27-28 is intended, then the author of Judges may have introduced "Beth Millo" as supporters of Abimelech as a way of alluding to Jeroboam I and the project that first elevated him to prominence. 
between the speech of Jotham to the Shechemites (Judg 9:7-20) and the address by Abijah to the people of the north (2 Chr 13:4-12). In the Abimelech narrative, Jotham, the one surviving son of Gideon, stands atop a hill (הר־גרזים, "Mount Gerazim") and yells out to the people of Shechem, "Hear me, O citizens of Shechem!" (שמעו אלי בעלי שכם, Judg 9:7), and accuses them of having "risen" (קום) against his father's family (Judg 9:18). Similarly, in 2 Chr 13:4, Abijah, the son of Rehoboam stands atop a hill (הר צמרים, "Mount Zemaraim") and yells down to the people of the north, "Hear me, O Jeroboam and all Israel!" (שמעוני ירבעם וכל־ישראל, 2 Chr 13:4) accusing the former of having "risen" (קום) against Solomon (2 Chr 13:6). The hilltop venue, the similarity of vocabulary and action undertaken, and the use in both cases of very similar phrasing (qal imperative masculine plural of שמע + subject) suggest that the actions of Jotham are intended to bring to mind the later actions of Abijah and his critique of the breakaway tribes and their rival monarchy.

The idea that the actions of Jotham function as a critique of the early northern monarchy is strengthened when one examines the content of Jotham's fable. Both speeches are connected by the fact that each functions as a complaint that legitimate rule has been rejected-in the case of Jotham that Gideon's family has been treated unfairly (Judg 9:16-20) and in the case of Abijah that David's house has been rejected (2 Chr 13:4-6). In Judg 9:8-13, the fable that Jotham tells clearly warns the hearers of the destructive consequences that will result from Abimelech's kingship. As much as it is a warning against the rule of Abimelech, however, the fable functions also as a criticism of appointing a king by popular acclaim. ${ }^{27}$ The fable begins with the unusual notation that, "the trees went to anoint a king over themselves" (הלוך הלכו העצים למשח עליהם מלך) - an unorthodox action in a social setting where monarchs were understood to be chosen by the deity (e.g., Psalm 2). As a group, the trees move from olive, to fig, to vine, offering the kingship. In each case, however, the prospect refuses, declaring that accepting the kingship would force them to forgo activities that would otherwise lead to the greater public good. Finally, the kingship is offered to the אטד (NRSV "bramble"). ${ }^{28}$ The point of the fable is that the people of Shechem have placed themselves in an untenable situation; having embarked on their chosen path, they will encounter violence if they accept the rule of Abimelech but also if they eventually reject it.

The warning embodied in Jotham's fable coheres well with what is known about the history of the northern monarchy. Apart from the brief rule of the

${ }^{27}$ O'Connell, Rhetorical Strategy of Judges, 164-66, 291; Richter, Traditionsgeschichtliche Untersuchungen zum Richterbuch, 287-93. Richter suggests that the fable alludes to the manner in which kings were selected in the northern monarchy.

${ }^{28}$ On the identification of the אטד, see Nogah Hareuveni, Tree and Shrub in Our Biblical Heritage (Kiryat Ono: Neot Kidumim, 1984), 59-65; and Michael Zohary, Plants of the Bible: A Complete Handbook to All the Plants with 200 Full-Color Plates Taken in the Natural Habitat (London/New York: Cambridge University Press, 1982), 154-55.

This article was published in JBL 131/3 (2012) 443-54, copyright (C) 2012 by the Society of Biblical Literature. To purchase copies of this issue or to subscribe to JBL, please contact SBL Customer Service by phone at 866-727-9955 [toll-free in North America] or 404-727-9498, by fax at 404-727-2419, or visit the online SBL Store at www.sbl-site.org. 
usurper Athaliah, the southern kingdom of Judah enjoyed the stability that came from being ruled by only one dynasty. By contrast, the northern monarchy, founded as it was by a ruler selected by popular acclaim, endured nine dynasties over a twohundred-year period, all of which ended with the violent death of their final member. The early history of the northern kingdom was particularly unstable, with three dynasties rising and falling within forty-six years and none of them managing to last to a third generation. Considered against the background of the history of Israel, Jotham's fable reads well as a clear critique of the manner in which the northern kingdom rejected the dynasty chosen by God and instead enthroned Jeroboam I by popular acclaim. ${ }^{29}$ This is suggested by the fact that the actions of the Shechemites in enthroning Abimelech are seen as ones of revolt and betrayal against the family of Gideon (9:16-20). The biting comments of Jotham in this passage correspond particularly well to the kind of resentment that a member of the house of David might have felt toward those who rejected the rule of his family. It is precisely this kind of sentiment that can be detected in the words of Abijah as he addresses the people of Ephraim from atop Mount Zemaraim (2 Chr 13:4-12).

An additional connection between the Abimelech narrative and the early northern monarchy may be present also in the story of Abimelech's unusual and violent death at Thebez. Following Yohanan Aharoni and Abraham Malamat, Anson F. Rainey suggests that it is likely that the MT reading "Thebez" (תבץ) is an early corruption of an original "Tirzah" (תרצה) - easily understandable given the similarity to rês and bêt in both paleo-Hebrew and Aramaic square script. ${ }^{30}$ If the

\footnotetext{
${ }^{29}$ In this vein, it is worth noting the way in which Abimelech is challenged by Gaal, son of Ebed ("loathsome, son of a slave") - a figure whose very name emphasizes his nonroyal status. The manner in which the commoner Gaal wins over the population of Shechem (Judg 9:26) and moves to seize power is characteristic of the political instability of the northern monarchy, where populism and regicide played a dominant role in royal succession. Note, for example, that the commoners Baasha, Zimri, Omri, Jehu, Shallum, Menahem, Pekah, and Hoshea each take the throne by deposing and killing their predecessor.

${ }^{30}$ Rainey and R. Steven Notley, The Sacred Bridge: Carta's Atlas of the Biblical World (Jerusalem: Carta, 2006), 140. See also Aharoni, The Land of the Bible: A Historical Geography (2nd ed.; Philadelphia: Westminster, 1979), 265; Malamat, "The Period of the Judges," in The World History of the Jewish People, vol. 3, Judges (ed. Benjamin Mazar; London: W. H. Allen, 1971), 320 n. 61. A common approach has been to equate Thebez with Tubas (185-192), a site three miles from Tirzah (Tell el-Fârcah; 182-188). Rainey, however, rejects Tubas as "not attractive phonetically." In this he is anticipated by T. K. Cheyne, who earlier observed that the Arabic place-name suggests a Hebrew țôbāss rather than tēbēz (T. K. Cheyne, "Thebez," Encyclopaedia Biblica [ed. T. K. Cheyne and J. Sutherland Black; Toronto: George N. Morang, 1903], vol. 4, col. 5033). See also Erasmus Gass, Die Ortsnamen des Richterbuchs in historischer und redaktioneller Perspektive (Abhandlungen des Deutschen Palästina-Vereins 35; Wiesbaden: Harrassowitz in Kommission, 2005), 333-34. In strategic terms, Tirzah is better suited to the text than Tubaș, since the former sits at the strategic crossroads of routes leading north to the Beth-shan valley, east to the ford of the Jordan at Adam (Tell ed-Dâmiyeh; 201-167), and west to Dothan (Tell Dôthān; 172-202) and
}

This article was published in JBL 131/3 (2012) 443-54, copyright (C) 2012 by the Society of Biblical Literature. To purchase copies of this issue or to subscribe to JBL, please contact SBL Customer Service by phone at 866-727-9955 [toll-free in North America] or 404-727-9498, by fax at 404-727-2419, or visit the online SBL Store at www.sbl-site.org. 
reading "Thebez" does represent a corruption of "Tirzah," then the violent death of Abimelech occurs at the location of the second capital of the northern kingdom and the very place where three of its kings-Abijah, Elah, and Zimri-met violent or premature ends (1 Kgs 14:12; 16:9-10, 18-19).

If the argument presented above is accepted, then we may have an explanation of the problematic name of Abimelech. ${ }^{31}$ Abimelech's name- "My father is king"is unusual for the simple reason that his father, Gideon, was not a king. If the Abimelech narrative has been shaped to denigrate the northern monarchy, however, the name Abimelech may be the author's way of drawing attention to this figure as another in history's long line of usurpers and would-be rulers who resorted to manufactured claims of legitimacy. ${ }^{32}$ This issue of legitimacy was exactly the problem faced by nine of the monarchs of the northern kingdom but one not encountered by the kings in Judah, all members of the house of David and undergirded by a promise given by Yahweh (2 Samuel 7).

The context of Judg 8:29-9:57 and its allusions to events in the history of the northern monarchy ${ }^{33}$ combine to show that the leadership of the northern monarchy was just as invalid as the failed leadership of the system of judges. While the book of Judges endorses kingship as the replacement for the judges, it is not an endorsement of any kingship. Gideon's refusal to accept kingship for himself or his descendants sets the precedent in which a northerner rightly refuses the crown when it is offered by the "men of Israel" (איש-ישראל) (Judg 8:22-23). ${ }^{34}$ For the Shechem of the period of judges and the early divided monarchy, rejecting a pre-

via it to the coastal plain. Given these qualities and the fact that it is closer to Shechem than Tubas, Tirzah is more likely to have been the target of a campaign by Abimelech.

${ }^{31}$ For a survey of the interpretations that have been proposed, see Daniel I. Block, Judges, Ruth (NAC 6; Nashville: Broadman \& Holman, 1999), 303-4.

${ }^{32}$ A prime example of this is Sargon of Akkad (ca. 2371-2316 в.C.E.), a usurper who takes a name meaning "legitimate ruler." A further example is the title adopted by the Hasmoneans,

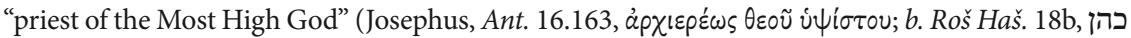
(גדול לאל עליון), a designation that overcomes the problem that the Hasmoneans were not from the Zadokite or Davidic lines by instead connecting their rule with that of the priest-king Melchizedek of Salem (כהן לאל עליון, Gen 14:18).

33 The name of Abimelech's chief supporter at Shechem may also constitute an allusion to the northern monarchy. One of the long-standing criticisms of the north was that it tolerated worship of the storm deity Baal (e.g., 1 Kings 17-18; Hos 2:8, 13 [Heb. 2:10, 15]; 11:2; 13:1). In the Abimelech narrative, the governor of Shechem is a certain Zebul (זבל), a figure whose name is well known as a title ("prince") of Baal known from Ugarit (e.g., KTU 1.2 I 38, 43; IV 8; 1.3 I 3; 1.5 VI 10). If the connection is deliberate, the name of Abimelech's adjutant may be intended to denigrate the northern monarchy by recalling the name of the deity both tolerated and promoted in the north (cf. 1 Kings 17-18).

${ }^{34}$ See Halpern for the interesting suggestion that Gideon, while rejecting the crown, uses the oracular powers of the ephod to retain a theocratic leadership role ("Rise of Abimelek BenJerubbaal," 84-88).

This article was published in JBL 131/3 (2012) 443-54, copyright (C) 2012 by the Society of Biblical Literature. To purchase copies of this issue or to subscribe to JBL, please contact SBL Customer Service by phone at 866-727-9955 [toll-free in North America] or 404-727-9498, by fax at 404-727-2419, or visit the online SBL Store at www.sbl-site.org. 
existing leadership and selecting a ruler based on popular acclaim usher in an era of instability and violence. Standing at the center of the book of Judges, the Abimelech narrative disposes of the idea that there might be a royal alternative to the leadership of the Davidic dynasty. The northern monarchy initiated by Jeroboam I was a model for ruin, not peace and stability. Recognition of this helps us to understand the crux of competing pro- and antimonarchic strands in Judges. If the foregoing is accepted, then we do not have contradictory pro- and antimonarchic strands in the book, but elements that endorse the leadership of Judah supported by those that denigrate Judah's royal rivals.

\section{Dating Anti-northern Polemic in Judges}

If the Abimelech narrative has been framed to denigrate the kind of kingship that dominated in the north, then a natural question is, When might this material have been added to the book of Judges? One historical period in which this material would have been rhetorically effective is in the time prior to 722 в.с.E. when the northern monarchy still existed as a rival to the kingdom of Judah. The fact, however, that some of the parallels noted above include close verbal or conceptual correspondences with passages from Chronicles points to a date for the final form in the postexilic period. While neither the southern nor northern monarchy existed in this era, similar issues of leadership and power were present. Palestine in the postexilic era was firmly under the control of Persia, but the region was not free from internal friction and power struggles. Immediately north of the fledgling province of Yehud lay the province of Samaria-a region populated by the descendants of the northern kingdom left behind following the destruction and exile of 722 B.C.E. While this group had intermarried with peoples introduced into the region by the Assyrians, they had retained something of their religious and national identity. In the time of Ezra and Nehemiah, these northerners were represented in part by a certain Sanballat the Horonite, who functioned as governor and was followed in this office by his descendants for several generations. ${ }^{35}$ In Nehemiah, this northern "dynast" was at the forefront of opposition to Judean attempts to establish themselves in Yehud and set up a viable government. ${ }^{36}$

Early in the postexilic era, the community of Yehud was led by several governors who also happened to be descendants of the royal house of David via

\footnotetext{
${ }^{35}$ In a letter from Elephantine in Egypt, Sanballat is mentioned as governor of Samaria assisted by his two sons (COS 3.51:125-30). A bulla of one of the sons of Sanballat identifying him as governor of Samaria was discovered at Wadi Daliyeh, north of Jericho (COS 2.78D:204). See also H. G. M. Williamson, "Sanballat," ABD 5:973-75; and Frank Moore Cross Jr., "Reconstruction of the Judean Restoration," JBL 94 (1975): 17.

${ }^{36}$ Nehemiah 2:10, 19-20; 4:1-3 (Heb. 3:33-35), 7-8 (Heb. 4:1-2); 6:1-14.
} 
Jehoiachin. ${ }^{37}$ During the Persian period, the Davidic-descended governor Zerubbabel was the subject of intense, but apparently short-lived "messianic" speculation (Hag 2:20-23; Zech 4:6-10a). The issue of the early governor's Davidic identity was clearly a touchy one for the leadership of the northern province. In a threatening letter to Nehemiah, Sanballat, the governor of Samaria, accuses the governor of Yehud of engaging prophets in Jerusalem to promote himself as a new king (Neh 6:5-7). From this, it is clear that in the postexilic era in Yehud, the issue of who would lead Israel-a member of the family of David or a northerner of mixed ancestry-was once again a topic of critical importance. For this audience, the story of Abimelech with its protagonist of dubious pedigree (cf. Judg 8:31; 9:18) and its clear denigration of northern traditions would have provided a clear message in favor of the Davidic-descended leadership of the Judeans. The emphasis on the Davidic house found in the parallel between the words of Jotham (Judg 9:7-20) and Abijah (2 Chr 13:4-12) would suggest that the Abimelech material-while perhaps originating during the divided monarchy-was given its final shape early in the postexilic era before the series of Davidic-descended governors of Yehud gave way to ones from outside the royal house.

\footnotetext{
${ }^{37}$ E.g., Sheshbazzar, Ezra 5:14; cf. 1 Chr 3:18; and Zerubbabel, Hag 1:14; 2:2. A bulla and a seal each mention another governor named Elnathan (COS 2.78B:203; 2.78C:203; see Nahman Avigad, Bullae and Seals from a Post-Exilic Judean Archive [Qedem 4; Jerusalem: Institute of Archaeology, Hebrew University, 1976], 5-7, 11-20, 31-35; and H. G. M. Williamson, "The Governors of Judah under the Persians," TynBul 39 [1988]: 69-74). Avigad's dating of the Elnathan bulla and seal would place this figure either immediately or shortly after Zerubbabel (Avigad, Bullae and Seals, 17, 35; followed by Eric M. Meyers, "The Shelomith Seal and the Judean Restoration: Some Additional Considerations," in Nahman Avigad Volume [ErIsr 18; ed. Benjamin Mazar and Yigael Yadin; Jerusalem: Israel Exploration Society, 1985], 33*-38*; William M. Schniedewind, How the Bible Became a Book: The Textualization of Ancient Israel [New York: Cambridge University Press, 2004], 173). The fact that Jehoiachin's maternal grandfather was named Elnathan (2 Kgs 24:8) makes it possible that, like Sheshbazzar and Zerubbabel, this figure may also have belonged to this branch of the Davidic house. As Cross notes, this would be in keeping with the Persian practice of appointing governors from the same family ("Reconstruction of the Judean Restoration," 15).
} 